\title{
The Positive Side of Feminist Theory in Entrepreneurial Finance: Feminist Themes and Tropes in Crowdfunding for Social Change
}

\author{
Theresia Harrer* \\ Middlesex University, London
}

\section{ARTICLE INFO}

\section{Article history:}

Received 03 July 2019

Revised 20 October 2019 \& 21

November 2019

Accepted 10 December 2019

Published 31 December 2019

\section{Keywords:}

Feminism

Social change

Entrepreneurship

Crowdfunding

Discourse analysis

\begin{abstract}
Following literature that already reframes entrepreneurship as a social change activity, I consider the societal change potential of entrepreneurial narratives in crowdfunding pitches of predominantly female-run ventures. I understand the community-driven phenomenon crowdfunding therefore as a vehicle to transcend and change the predominantly masculine entrepreneurial discourse of innovation and business success. Following an idiographic methodology, I analyse the discourse in crowdfunding video-representations of female-run ventures and explore structure, linguistic usage, visual artefacts and the implied intentions towards social change from a feminist perspective. From the sampling set of 42 crowdfunding campaigns, I use the resulting discursive elements and tropes to identify feminist themes that drive the success of these campaigns through connecting with immanent societal values. With this I contribute to the social change perspective in entrepreneurship research by addressing epistemological issues within prevailing paradigms.
\end{abstract}

\section{Introduction}

The sustainability discourse in the field of entrepreneurship is often associated with hybrid organisational forms (Battilana and Lee, 2014; Lehner and Weber, 2016) and looked at from an environmental (Meek et al., 2010) or internal social innovation perspective (Gerber and Hui, 2013; Youssef et al.; Munoz and Cohen, 2017) only. When it comes to analysing, for example performance such endeavours often seem to follow a functionalist paradigm that does not fully capture the social discourse underlying funding processes. Thus, existing research on entrepreneurship may limit potential constructivist inquiries towards the much needed conceptualisation of the social movemententrepreneurship nexus from a social change perspective (Nielsen and Reisch, 2016). Despite this limitation, it has become clear that research on entrepreneurship needs to include sustainability and social criteria from a constructivist point of view in order to depict the socio-economic context in its discourse (Haugh, 2005; Haugh and Talwar, 2016; Lehner, 2012). This is especially true if ventures with a social mission seek funding from the crowd (Brown et al., 2018; Landström et al., 2019; Lehner, 2013).

Subsequently, there is an evident need for new research perspectives to include social change as an underlying current that comprises elements of both, radical innovation and financial performance. In doing so, due to its critical epistemological positioning (Calas et al., 2007; Calas et al., 2009; Adkins, 2004; Stanley, 2013) feminist theory seems to provide an encouraging avenue to better understand socially constructed phenomena. More importantly, it provides the potential to incorporate the radical change character in the understanding of entrepreneurial motivation (Dey, 2007; Dey and Steyaert, 2012).

Looking at predominant entrepreneurship theory from a feminist perspective, scholars such as Marlow and Swail (2014); Marlow and McAdam (2013); Ahl and Marlow (2012); and Marlow and Patton (2005) have demonstrated

* Corresponding author.

E-Mail address: TH588@live.mdx.ac.uk 
that, so far, feminist critique often falls into the "gender-only"-trap. The concept of gender is reduced to sex and ultimately research is devoted only to a situational analysis from a narrow perspective. It therefore furthers a certain discourse in which masculinity is seen as the ultimate norm that entails all power issues within this narrow perspective. Existing critique thus often fails to adequately address overarching and dynamic power issues in a socially constructed system and hence does not incorporate real (social) change perspectives - instead, in its current epistemological state it cements gender inequalities by constant repetition of findings based on a false precondition.

In order to meet both social and entrepreneurial underpinnings, I borrow from Calas and Smircich (1999); Calas et al. (2009) and apply feminist theory as an apt lens for looking at the change potential of crowdfunding campaigns. From the many important faces of feminist theory (Pettersson et al., 2017), two mainstream approaches - liberal and social feminism - can be recognised. First, critique stemming from a feminist perspective offers avenues into a more fine-grained understanding of the growing change intention of entrepreneurs, for example in social entrepreneurship. Furthermore, in order to facilitate a more holistic concept of gender in entrepreneurship literature, Marxist or even stronger radical approaches are seen as proponents that can potentially enhance prevailing epistemological assumptions helping to overcome shortfalls (Calas et al., 2007; Calas et al., 2009).

A phenomenon in entrepreneurship that is especially exposed to the often-contradictory investment and opportunity logics in entrepreneurship is crowdfunding (Lehner and Nicholls, 2014). For example Lehner (2013) highlights that research avenues in crowdfunding for social ventures must cover both, rational financial logic, but also need to include socially constructed motivations and intentions. Still, crowdfunding is often linked to the promised innovation and the respective market potential in the fund-seeking ventures and thus is evaluated by functionalist, reductionist metrics rather than by looking at the proposed theory of societal change. (Parhankangas and Renko, 2017; Mollick, 2014; Belleflamme et al., 2014)

In the light of this, I use research on crowdfunding from a feminist theory perspective as an innovative avenue to enhance the understanding of entrepreneurial intentions, and ultimately strengthen the argument for a better inclusion of discursively created social change aspects in entrepreneurship. With respect to the many feminist approaches, this paper sticks to the mainstream liberal and social approaches as I aim to connect to existing entrepreneurship literature on social change intentions in entrepreneurial narratives. In particular, by looking at female run crowdfunding ventures, I want to find out whether the prevalent positivist epistemological thinking can fully comprehend the "whatness" of crowdfunding as a socio-economic phenomenon and how a feminist perspective can enhance both, theory and practice of crowdfunding by including discursive social change aspects.

Thus, the following research questions have been established to guide my field work:

RQ1: From a feminist perspective, what are the rhetorical strategies employed by female entrepreneurs in their narratives in crowdfunding campaign videos?

RQ2: Which themes based on socially constructed values are the most common in crowdfunding campaigns initiated by female entrepreneurs and how do these connect to existing feminist theory?

The paper proceeds as follows. In the first section, I revisit contemporary literature on prevailing entrepreneurial assumptions and highlight the importance of acknowledging both functionalist and constructivist research avenues. To further elaborate on this in the changing rationale of entrepreneurship towards a social change perspective, I revisit the concept of entrepreneurial narratives, which act as a sort of transmitter of values and hence entrepreneurial intentions. Ultimately, these narratives provide the theoretical base for the empirical examination.

In the second part, I conduct a Foucauldian discourse analysis (Foucault, 1982) built upon the aforementioned socio-constructivist approaches. I select representative reward based crowdfunding campaigns, primarily from the platforms Indiegogo.com and Kickstarter.com, analyse their pitch videos and extract information including content, discourse and visual artifacts to ascertain how feminist themes are used in the crowdfunding discourse to drive social change through entrepreneurship. Some of the findings include female empowerment, self-determination and realization, reflective body and self-image, women's and family health, the sharing economy and community orientation. The research model on entrepreneurial (crowd)funding pitches, which includes the triad of: discursive elements as tropes, artifacts as tangible symbolic expressions, and finally feminist themes as entrepreneurial intentions, provides an early indication of how a pragmatist epistemology can look like, which respects traditional functionalist perspectives but acknowledges the constructivist and critical view on entrepreneurial intentions. 


\section{Social change perspectives in entrepreneurship literature}

Entrepreneurship as a field of research has often been looked at from a functionalist perspective and hence been determined as driven by mechanisms such as opportunity recognition (Busenitz et al., 2003). Consequently, entrepreneurship can be explained as "the nexus of opportunities, enterprising individuals and teams, and mode of organizing" (297). This prevalent focus on economics or finance logics centres the role of entrepreneurs and their potential for exploration and exploitation of innovative ideas. The overall focus is hence set on entrepreneurial behaviours but leaves out necessary indications on how the underlying discourse of the organisation influences its performance internally as well as externally.

Research scholars often aim to explain what makes ventures more successful from an internal side, but still do not deliver clarity to entrepreneurial success from a grounded, yet more collective societal perspective. Continuing the perspective of a successful venture, not only is the internal recognition of opportunities crucial but also the creation of external entrepreneurial legitimacy (Tost, 2011; Suchman, 1995). The latter concept can only be understood by taking into account the contextual value systems and thus aims to understand the prior-stated grounded societal constitutions of success. Such contextual value systems strongly rely on societal values and hence ask for a broader perspective rather than a purely functionalist one. Thus, acknowledging the lack of clarity in conceptualisations of socio-economic phenomena such as crowdfunding, it seems apt to scrutinize the social counterpart in entrepreneurship theory.

Contributing to the critique on mostly functionalist notions in entrepreneurship, Steyaert (2007); Haugh (2005) already state that taking into account broader contextual dynamics in the prevalent economic logics may depict a fundamental change in contemporary thinking. Such notions contribute to a critique stemming from a social change perspective and may address the earlier findings of Shane and Venkataraman (2000) that the field of entrepreneurship is still trapped in a dilution of the explanation of many phenomena within. Offering a more critical perspective on prevalent assumptions in entrepreneurship, Calas et al. (2009) also take issue with the singularity of the perspectives on entrepreneurship. In their work they come up with the definition of entrepreneurship as "a social change activity with a variety of possible outcomes" (553) and find it difficult to bring research forward because of the difficult ontological status of the combination of social change and entrepreneurship. These works already highlight that entrepreneurship research can only move forward by fully advancing current (often somewhat static) phenomenadriven research into a theory-driven agenda.

Traditional approaches towards the examination of the position of women in entrepreneurship often only stem from a realist rationale (Burrell and Morgan, 1979) and thus seem to ignore more constructivist factors which deal with the question why and how such intentions of value-creation are shaped. Calas et al. (2009) distinguish between three perspectives on entrepreneurship. First, they state that entrepreneurship as positioned in a functionalist paradigm mostly describes the nexus of opportunities, growth and value creation. Second, they see liberal, psychoanalytic and radical feminist perspectives as a critical avenue towards entrepreneurship as a social change activity that may benefit women. Such approaches especially highlight the different values of women, based on which they argue for potential opportunities in an entrepreneurial context. Last and third, the authors state that a socialist, poststructuralist and transnational feminist perspective offers a critical yet explanatory avenue towards a gendered social change view regarding entrepreneurship. Building on the above perspectives on entrepreneurship it becomes obvious that the often-remarked position of gender in feminist theories leaves room for interpretation. It further highlights that feminist theory might offer promising insights into the constitutional elements of an entrepreneurial discourse.

\section{Feminist theory as apt critical perspective}

Taking on the idea of a critique on entrepreneurship research based in feminist theory, Radford (2013) adds that men are more likely to receive funding than their female counterparts. Earlier, Marlow and Patton (2005) already see a disadvantage of women in accessing business funding. Combining this critique with prior-mentioned functionalist approaches in entrepreneurship, a performance and success measurement mostly taking into account financial metrics makes it valid to assume that men also outperform women (Marlow and McAdam, 2013). Such an idea however leaves one asking whether this really marks the difference between male and female entrepreneurs (Jennings and Brush, 2013) and their juxtaposed evaluation (Neergaard et al., 2011; Ahl, 2006). What has become obvious is that women intend to create and signal different values than men, which ultimately shapes the overall value of their ventures. This makes the position of women even more difficult in a male run world and, at the same time, the fact 
that there is a strong relationship between women and social change movements is pertinent for further research (Thon, 2017).

This becomes clear when Marlow and Swail (2014); Marlow and McAdam (2013); and Ahl and Marlow (2012) point out that critique in traditional and often functionalist entrepreneurship was originally designed to explain gender-differences within entrepreneurship research. Highlighting the socio-economic context in which conceptual assumptions and thus women's subordinations are justified, the aim of critique thus drifted towards offering insights into behavioural differences between men and women, ultimately attempting to explain the often-prevalent underperformance of female entrepreneurs. However, reflexive assumptions concerning the hierarchical positioning of women in the concept of gender also limit the underlying discourse. These assumptions even predefine a certain discourse in which masculinity is seen as an ultimate norm and entails all power issues within this narrow perspective, therefore limiting the potential of poststructuralist feminist approaches as proposed in Calas et al. (2009). Based on this, it seems necessary to focus on an underlying societal discourse within entrepreneurship literature in order to explain a venture's success.

Acknowledging the potential of feminist theory as a critical perspective towards entrepreneurship as social change process and tracing assumed (gender-) differences back to social values, I am able to position the thoughts within a feminist agenda. This is not only because gender notions reflect inherent differences between men and women, but also because from a more radical perspective, feminist theory aims to induce social change by addressing relevant societal issues and thus offers critical avenues for explaining the prior mentioned issues via the conceptualization of phenomena such as social finance. Thus, following Pettersson et al. (2017); Calas et al. (2007), the main streams of feminism that are essential in entrepreneurship research are described in Table 1. This table also incorporates their main implications for society and their theoretical backgrounds.

Table 1. Feminist Approaches in Entrepreneurship adapted according to Pettersson et al. (2017)

\begin{tabular}{|c|c|c|}
\hline Feminist Approach & Implication & Relevant References \\
\hline liberal & $\begin{array}{l}\text { The difference between men and } \\
\text { women arises due to the different } \\
\text { access to essential resources. }\end{array}$ & $\begin{array}{l}\text { (Calas et al., 2007) (Cowling and } \\
\text { Taylor, 2001) (Calas and Smircich, } \\
\text { 1996) (Fischer et al., 1993) (Friedan, } \\
\text { 1963) }\end{array}$ \\
\hline socialist & $\begin{array}{l}\text { The difference is innate due to power } \\
\text { relations in a capitalist economic } \\
\text { system. Gender topics are often related } \\
\text { to entrepreneurship. }\end{array}$ & $\begin{array}{l}\text { (Carter and Williams, 2003) (Calas and } \\
\text { Smircich, 1996) (Fischer et al., 1993) } \\
\text { (Cliff, 1998) (Black, 1989) }\end{array}$ \\
\hline poststructuralist & $\begin{array}{l}\text { The difference between men and } \\
\text { women is represented by the used } \\
\text { language. Texts and languages are used } \\
\text { as politics of representation and } \\
\text { connect to social reality. }\end{array}$ & $\begin{array}{l}\text { (Calas et al., 2007) (Calas and } \\
\text { Smircich, 1999) (Alcoff, 1988) (Fraser } \\
\text { and Nicholson, 1988) }\end{array}$ \\
\hline postcolonial & $\begin{array}{l}\text { The western feminist approaches } \\
\text { investigate the function of "the nation". } \\
\text { Thereby they often gender and racialize } \\
\text { others as well. }\end{array}$ & $\begin{array}{l}\text { (Calas et al., 2007) (Collins, 2002) } \\
\text { (Kaplan and Grewal, 1999) } \\
\text { (Mohanram, 1998) }\end{array}$ \\
\hline radical & $\begin{array}{l}\text { Alternative and often separatist } \\
\text { arrangements are proposed in order to } \\
\text { raise consciousness. }\end{array}$ & $\begin{array}{l}\text { (Calas et al., 2007) (Greer and Greene, } \\
\text { 2003) (Tong, 1998) (Ferree and Martin, } \\
\text { 1995) (Brown, 1992) }\end{array}$ \\
\hline psychoanalytic & $\begin{array}{l}\text { The difference between men and } \\
\text { women arises due to prevalent } \\
\text { patriarchal family and education } \\
\text { systems. These cause unequal } \\
\text { development of men and women. }\end{array}$ & $\begin{array}{l}\text { (Calas et al., 2007) (Tong, 1998) } \\
\text { (Noddings, 1984) (Gilligan, 1982) } \\
\text { (Mitchell, 2000) }\end{array}$ \\
\hline
\end{tabular}


Besides providing the necessary critical distance, poststructuralist feminist approaches have the potential to soften conceptual boundaries in current research and enhance paradigmatic assumptions (Ahl and Marlow, 2012). For example, by borrowing from liberal feminism in a poststructuralist agenda, existing inequalities can be traced back not only to gender but to a broader system of power imbalances. Thus, critique stemming from a feminist perspective can be used to fully explain the dynamics of the underlying discourse in a social system and promote change of prevalent norms, which is also necessary for taking into account the social extents of entrepreneurship. The deconstruction of concepts such as gender in an overarching social system can potentially dismantle this narrow and ineffective critique.

Such adaptions can even be fostered by feminist theory as a radical element (Hall, 1980; Morgan, 1980). For this purpose, McRobbie (2009); Agger (2006) highlight in particular the task of illuminating socio-cultural issues. For example, Adkins (2004) earlier sees that social theories have often neglected feminist theory because of its critique on a broader context, which is not limited to the concept of gender. Based on this, Adkins (ibid) describes a sociocultural context as promising for adopting feminism in social theory. She borrows from humanities and social science disciplines to critically analyse contemporary (societal) issues using so-called constructivist structuralism (Fowler, 2000). This may further indicate that social theory can offer a critical, albeit markedly different deployment of feminist theory in terms of epistemological positioning (Butler and Elliot, 1993; Fraser, 1997).

\section{Entrepreneurial narrations}

Noting that external legitimacy and thus venture success is often closely related to a communicated story and history, I see that (entrepreneurial) narratives offer relevant avenues for explaining the intended discourse in a story (Herzenstein et al., 2011). These narratives are strongly dependent on linguistic tools. For example, Labov (1972) already defines narrative as "one method of recapitulating past experience by matching a verbal sequence of clauses to the sequence of events which (it is inferred) actually occurred" (pp. 359-360). Considering an entrepreneur's story, it seems legitimate to assume that each entrepreneur uses a certain set of narratives and by that refers to past events with the linguistic tools used. Hence, by using entrepreneurial narratives in their story, they reference back to a certain culture of the people used to express their stories.

However, in entrepreneurship literature, Venkataraman et al. (2013) already see that narratives are descriptions of human nature and thus shape our cultural representations. More importantly, these narratives construct and explain a social reality to its underlying processes because they are accepted cultural representations. By doing so, they are capable of influencing a venture's growth strategy and ultimately its performance compared to the market. Thus, in order to increase external legitimization and hence attract investors by creating widely accepted meanings, entrepreneurs are held to create strong entrepreneurial narratives. Putting these meanings into a certain context, they can be depicted as certain themes. Lewis and Carley (2017) for example already find that such themes both co-occur and overlap with the individual narratives in an entrepreneurial context. However, this notion of similarity alone does not explain the important external legitimization of a venture; Lewis (2014) points out that the discourse is created by narratives and themes, which are the crucial aspects of a story and thus a venture's success.

In social discourse narratives are perceived differently by each recipient of a story. While transmitters (entrepreneurs) use narratives to shape their cultural representation by linguistic toolkits, recipients inevitably make meaning of this by plotting narratives in the shape of artefacts. These artefacts can thus be understood as a physical representation of narratives (Venkataraman et al., 2013). To further create a more legitimized value for such artefacts, based on Venkataraman et al. (ibid) I introduce the concept of tropes. These tropes are described as the valuetransporting element in the overall legitimization process of a venture and can induce a transformation into themes by linking them to a certain (social or cultural) context.

Linking these above thoughts of narratives and themes to poststructuralist feminism (Calas et al., 2009), I see the connection in the usage and analysis of linguistic tools. The concept of entrepreneurial narratives and the critique stemming from a feminist perspective manifest their potential to disperse prevalent structures in a discourse while also explaining its descriptive potential. So far, this potential has not yet been fully exploited, because contemporary research scholars in entrepreneurship mostly remain in a functionalist paradigm and have simultaneously failed to make adequate use of the interdisciplinary concept of entrepreneurial narrations for an opening towards a theory of social change. Shiller (2017) takes on this issue and recently called for a further inclusion of narratives (and thus socially constructed themes) in research fields such as finance and entrepreneurship. Based on this, I note that entrepreneurial narratives depict social values and can thus be seen as a crucial in the overall value-creation of ventures. 


\section{How it all fits together: entrepreneurial (crowd)funding narrations and feminist theory}

Seeing crowdfunding as especially exposed to complex socio-economic discourses because of its dualistic (socioeconomic) avenues, feminist approaches can help to explain a necessary shift from a pure functionalist towards a more critical, yet constructive research agenda. Due to their critical epistemological positioning, feminist approaches dig underneath prevalent conceptualizations - for instance gender in entrepreneurship literature - and foster an understanding of the discourse within. This ultimately imposes the need for new, yet multidisciplinary research avenues.

Crowdfunding is characterised by its inherent value proposition of a co-creation of opportunities for the many internal and external actors (Landström et al., 2019; Lehner and Harrer, 2019; Brown et al., 2018). Polzin et al. (2018) for example highlight the many different perceptions between the internal and external actors, indicating the importance of perceived narratives. Yet, such differences can lead to a more powerful process of innovation and hence a better external legitimisation, because the transfer of economic capital is moderated by how actors interact with each other in a social discourse (Lehner, 2013; Lehner, 2014). Hence, based on such transformation processes legitimisation strategies may need to adapt accordingly but are inherently difficult to grasp without the understanding of the underlying discourse (Lehner et al., 2019; Lassen, 2016; Parhankangas and Renko, 2017). In addition, the collective knowledge of the crowd, which is often termed the "wisdom of the crowd" (Lehner, 2014; Brown et al., 2018), is initially dispersed and later bundled through the interplay of many actors and activities (Lehner and Harrer, 2019). These inquiries already show that many tiers of social capital may influence and create the important discourse within a funding process via crowdfunding.

Furthermore, an entrepreneur's inherent characteristics, such as gender, social class, geographic origin and scope, education and linguistics represent influential signals and can be factors determining the overall success of a crowdfunding campaign (Shane and Khurana, 2001). This corroborates the findings of Lehner (2014) and Colombo et al. (2015), who demonstrate that democratic participation between the different tiers of social capital determines whether a crowdfunding campaign will be successful. I could thus postulate that entrepreneurs will inevitably create a strong narrative in order to successfully promote an innovation-induced change. These characteristics make it especially relevant to understand the multi-step discourse in the entrepreneurial and social value creation which makes crowdfunded ventures successful.

\section{Sampling and methodology}

In order to identify relevant themes and analyse the social discourse (Hardy and Thomas, 2015) in crowdfunding campaigns I conduct a Foucauldian discourse analysis (Foucault, 1982). This process enables an analysis of the set power issues in themes (Denzin and Lincoln, 2011), which I find are especially relevant in feminist theory. Based on this, I present the findings in the model of "Artefacts in the Triad of Elements, Tropes and Feminist Themes" (see Figure 1) and thereby aim to visualise internal and external value creation in crowdfunding pitches. 


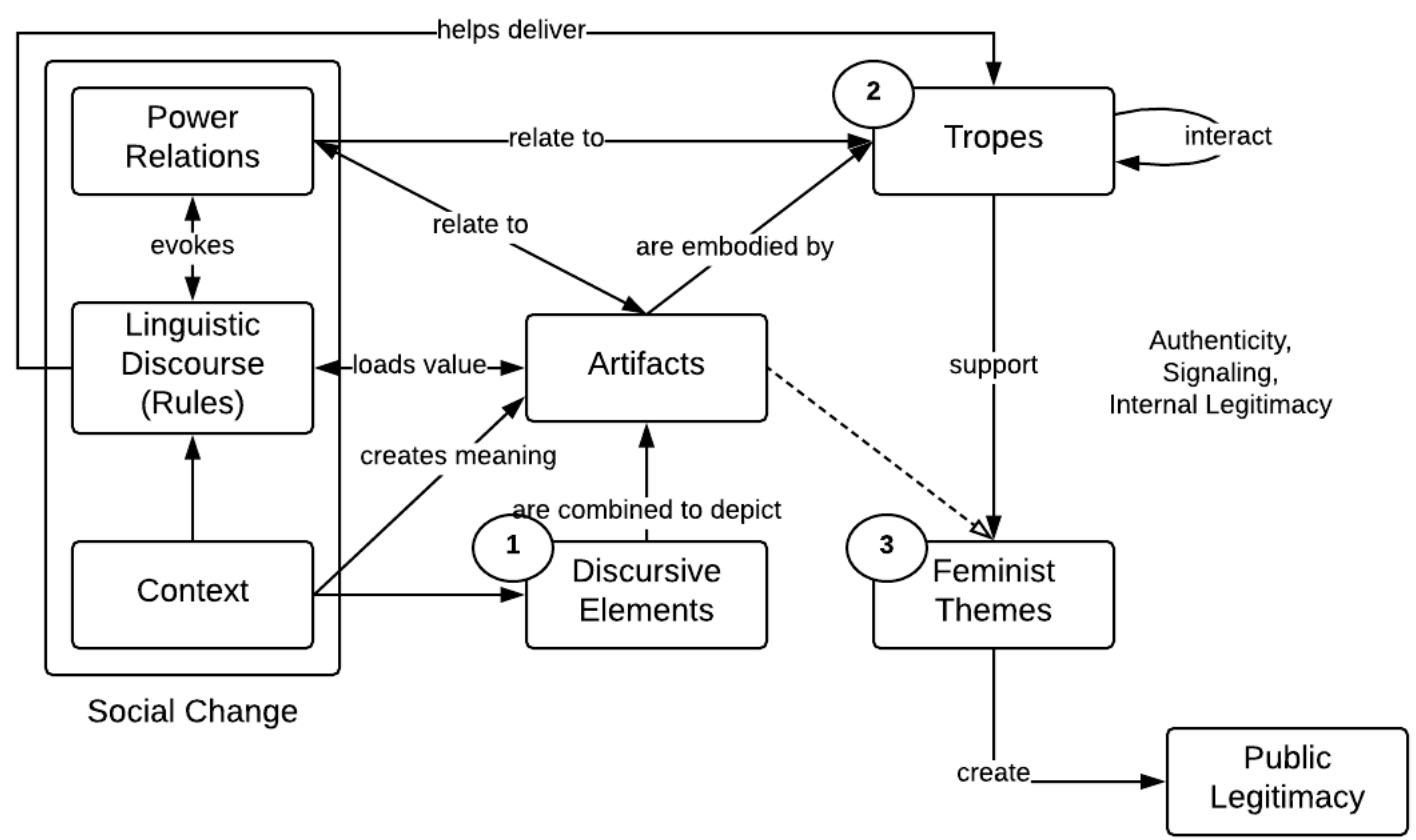

Figure 1. Artefacts in the Triad of Elements, Tropes and Feminist Themes (developed by the Othmar Lehner and Theresia Harrer, 2018)

First, I establish selection criteria for the selection of crowdfunding campaigns. These include for instance general social or environmental relevance of the project (e.g. supporting people in reaching their fitness goals or producing sustainable dolls for disadvantaged communities) or female issues (e.g. tackling the period pain stigma or awareness for breastfeeding). Some unsuccessful campaigns are selected in order to come up with the themes for successful crowdfunding inquiries. Campaigns are primarily collected from the crowdfunding platforms Indiegogo.com and Kickstarter.com. By following the thoughts that (radically) innovative ideas are often induced by societal values and hence are socially constructed, my campaigns primarily cover ideas with an innovation-induced change character. In addition, in line with the primarily addressed issues of female entrepreneurs being exposed to difficulties in performing on par with their male counterparts due to a different subjective set of values, I choose campaigns which have been initiated by women and thus have a strong connection with social change issues.

In the second step, a close analysis of the selected crowdfunding campaigns is conducted. True to my idiographic methodology, the campaign videos are analysed first in terms of their overall (societal) impact score, second the feminist score and third the constitution of the entrepreneurial teams (see Appendix B). In addition, I assess the respective pitch-video according to the intended discourse, depicted artefacts by their rhetorical strategies and also the overall content of the story. Particularly, in order to describe artefacts of each video, I analyse rhetorical means as discursive elements which indicate and intend a certain outcome in the form of artefacts (Venkataraman et al., 2013). Based on these artefacts certain tropes are produced, which actively support the external legitimisation process of a campaign in order to attract investors. Corroborating these steps, for each campaign video I come up with numerous discursive elements, which provide the basis for three feminist tropes (see Table 2).

Table 2. Exemplary Evaluation as of Tropes

\section{Exemplary Evaluation Case She Started It Documentary Phase [0110]}

Fem. Impact Team Constitution* Discursive Elements

Score Score

$4 \quad 3-4 \quad 1$

Anaphor (combine for Artifacts)*

Community Sense

Clumsy Music

$*(1=\mathrm{f}, 2=\mathrm{m}$

$3=$ mixed)

*from video evaluation
Tropes $(3)^{*}$

Innovative Incubator
Strong Woman
Tech Woman
*from video
evaluation

evaluation

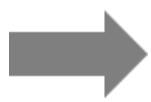


In the third step, in a recursive and iterative process I analyse the context of each pitch-video and by doing so I am able to inductively arrive at distinct themes. Following feminist literature, I see relevant feminist themes such as the position and perception of women in professional, administrative and domestic spheres (Coppock et al., 2014; Harding, 2004). Themes such as equal opportunities, oppression, family, sexuality are thus explored in the leverage of institutional power issues, albeit often with the focus on pre-defined and repeated gender differences. In addition to this, Haugh and Talwar (2016) see the theme of empowerment as strongly linked to social change and thereby highlight the relevance of social and liberal feminist approaches for societal change issues. Acknowledging these apriori identified feminist themes, I further add relevant themes which I extract from the selected crowdfunding campaigns (see table 3). Furthermore, acknowledging tropes as visualization of entrepreneurial narrations (which already signal strong internal legitimacy), I oppose them to a collective societal discourse and corroborate tropes as themes. This ultimately allows for an assessment of the explanatory potential of feminist theory with a socially constructed discourse in crowdfunding campaigns.

Table 3. Exemplary Evaluation as of Feminist Themes

\begin{tabular}{cc}
\hline Exemplary Evaluation She Started It Documentary Phase [0110] \\
\hline \multicolumn{1}{c}{ Tropes (3)* } & Feminist Themes (2)** \\
Entrepreneurship & Women's Empowerment \\
Strong Woman & Deconstruction of Gender \\
& \\
Tech Woman & \\
$*$ from video & $* *$ from video evaluation \& \\
evaluation & literature \\
\hline
\end{tabular}

Following this methodology, I select 42 campaigns on (primarily) reward based crowdfunding platforms such as Kickstarter.com [0300000], Indiegogo.com [0100000], Indiegogo-Generosity.com [0200000] and Patreon.com [0400000]. In total, 50 discursive elements, 30 tropes and 26 themes are identified. A detailed list can be found in Appendix C. The crowdfunding platforms are selected because they provide sufficient crowdfunding campaigns in order to be able to draw reasonable conclusions. Table 4 provides relevant statistics on the selected cases. A detailed list of these can be found in Appendix A.

Table 4. Statistics of Selected Cases

\begin{tabular}{llllll}
\hline \multicolumn{1}{c}{ Platform } & \multicolumn{1}{c}{ Total } \\
\hline & Indiegogo & Kickstarter & $\begin{array}{l}\text { Indiegogo } \\
\text { Generosity }\end{array}$ & Patreon & 4 \\
Number of Cases & 20 & 18 & 2 & 2 & 42 \\
$\begin{array}{l}\text { Number of } \\
\text { Documents }\end{array}$ & 109 & 126 & 8 & 9 & 257 \\
$\begin{array}{l}\text { Total Funding } \\
\text { Sum Platform }\end{array}$ & $\$ 800,000,000.00$ & $\$ 2,973,461,408.00$ & $\mathrm{n} / \mathrm{a}$ & $\$ 8,991,874.00^{1}$ & $\$ 3,782,453,282.00$ \\
$\begin{array}{l}\text { Total Funding } \\
\text { Sum of Cases }\end{array}$ & $\$ 6,467,542.86$ & $\$ 4,662,127.50$ & $\$ 9,743.00$ & $\$ 41,368.42^{2}$ & $\$ 11,180,781.78$ \\
\hline
\end{tabular}

With a total of 18 projects on Kickstarter (total investment sum \$2,973,461,408), 20 on Indiegogo (total investment sum $\$ 800,000,000$ ), two on Indiegogo-Generosity and three representative cases on Patreon (total monthly pay-outs $\$ 8,991,874$ ), the research results in 257 documents and 38 campaign videos. The projects have an

${ }^{1}$ Of payouts on a monthly basis

${ }^{2}$ Of payouts on a monthly basis 
overall funding value of approximately $\$ 11,180,800$. Cases which do not primarily offer a video on the crowdfunding platform are analysed using various collected documents with the aim of identifying their discursive elements and hence the stream of their respective feminist theme and external legitimacy.

\section{Empirical findings}

In the a-posteriori data collection and knowledge creation I conceptualise the inquiries as shown in figure 1 . In the following sections, I describe the most obvious and frequently used tropes and themes. The number in brackets shows how often each is used in the selected cases. Furthermore, I note that discursive elements are at the very bottom of the creation of a social discourse and thus these are not restricted to a certain number.

\section{Tropes}

Seeing tropes and rhetorical artefacts as empirical building blocks as described in the methodology, the following section refers to the five most frequent tropes. Discursive elements as a base of entrepreneurial narratives and artefacts are used as indicators for the overall depiction of these tropes. Although they only allow for a vague generalisation as a story is perceived differently by every recipient and are thus more relevant for internal legitimacy, these indicators can also be seen as indicators with regards to external legitimacy. Table 5 describes the five most frequent tropes and is related to the above-mentioned activity system approach. This approach allows me to show the exemplary cases, which are indicated by the number in square brackets.

Table 5. Identified Tropes

\begin{tabular}{|c|c|c|c|c|c|}
\hline $\begin{array}{l}\text { Most Frequent } \\
\text { Tropes }\end{array}$ & $\begin{array}{l}\text { Innovative } \\
\text { Incubator (12) }\end{array}$ & $\begin{array}{l}\text { Sense of } \\
\text { Community (11) }\end{array}$ & $\begin{array}{l}\text { Strong } \\
\text { Woman (11) }\end{array}$ & $\begin{array}{l}\text { Natural } \\
\text { Woman (8) }\end{array}$ & $\begin{array}{l}\text { Uncommitted } \\
\text { Sexuality (7) }\end{array}$ \\
\hline $\begin{array}{l}\text { Related Subject in } \\
\text { Video }\end{array}$ & $\begin{array}{l}\text { governmental } \\
\text { restriction, } \\
\text { rationality, } \\
\text { different cultures, } \\
\text { demanded } \\
\text { innovations in a } \\
\text { saturated market, } \\
\text { new generation, } \\
\text { heritage, societal } \\
\text { economy }\end{array}$ & $\begin{array}{l}\text { doing-good, } \\
\text { NGOs, } \\
\text { aboriginal culture, } \\
\text { nature }\end{array}$ & $\begin{array}{l}\text { societal doing- } \\
\text { good, } \\
\text { modern } \\
\text { lifestyle, } \\
\text { activeness, } \\
\text { theatre/film } \\
\text { culture, } \\
\text { heroes, } \\
\text { showing } \\
\text { character }\end{array}$ & $\begin{array}{l}\text { stressful } \\
\text { motherhood, } \\
\text { innocent } \\
\text { women, } \\
\text { alternative food } \\
\text { - superfood, } \\
\text { doing-good }\end{array}$ & $\begin{array}{l}\text { openness/ } \\
\text { talking about } \\
\text { taboos, } \\
\text { distance } \\
\text { relationship, } \\
\text { cultural heritage, } \\
\text { showing } \\
\text { character }\end{array}$ \\
\hline $\begin{array}{l}\text { Related Object in } \\
\text { Video }\end{array}$ & $\begin{array}{l}\text { environment, } \\
\text { a movement, } \\
\text { desktop hive for } \\
\text { insects, } \\
\text { art, } \\
\text { bike locker, } \\
\text { technological } \\
\text { devices, } \\
\text { cookbook, } \\
\text { documentary }\end{array}$ & $\begin{array}{l}\text { (kids') cookbook, } \\
\text { baby carriers, ice } \\
\text { cream shop, } \\
\text { clothing, } \\
\text { touches, } \\
\text { music album, } \\
\text { art }\end{array}$ & $\begin{array}{l}\text { social work, } \\
\text { menstrual pain, } \\
\text { clothing, } \\
\text { documentaries, } \\
\text { training, } \\
\text { comics, } \\
\text { play } \\
\text { production, } \\
\text { tech necklace }\end{array}$ & $\begin{array}{l}\text { dried veggie } \\
\text { blend, } \\
\text { music video, } \\
\text { bra, } \\
\text { book, } \\
\text { touches, } \\
\text { desktop hive for } \\
\text { insects }\end{array}$ & $\begin{array}{l}\text { menstruation, } \\
\text { art, } \\
\text { photo book, } \\
\text { documentary, } \\
\text { touches, } \\
\text { comics }\end{array}$ \\
\hline
\end{tabular}




\begin{tabular}{llllll}
\hline $\begin{array}{l}\text { Most Frequent } \\
\text { Tropes }\end{array}$ & $\begin{array}{l}\text { Innovative } \\
\text { Incubator (12) }\end{array}$ & $\begin{array}{l}\text { Sense of } \\
\text { Community (11) }\end{array}$ & $\begin{array}{l}\text { Strong } \\
\text { Woman (11) }\end{array}$ & $\begin{array}{l}\text { Natural } \\
\text { Woman (8) }\end{array}$ & $\begin{array}{l}\text { Uncommitted } \\
\text { Sexuality (7) }\end{array}$ \\
\hline Salient Examples & {$[0101 ; 0104 ; 0110 ;$} & {$[0115 ; 0117 ;$} & {$[0108 ; 0109 ;$} & {$[0102 ; 0104 ;$} & {$[0108 ; 0122 ;$} \\
& $0111 ; 0214 ; 0120 ;$ & $0118 ; 0323 ; 0328 ;$ & $0110 ; 0112 ;$ & $0107 ; 0119 ;$ & $0326 ; 0327 ;$ \\
& $0328 ; 0330 ; 0331 ;$ & $0331 ; 0333 ; 0335 ;$ & $0122 ; 0214 ;$ & $0120 ; 0326 ;$ & $0334 ; 0339 ;$ \\
& $0336 ; 0337 ; 0441]$ & $0336 ; 0339 ; 0340 ;$ & $0323 ; 0329 ;$ & $0327 ; 0339]$ & $0441]$ \\
& & $0441]$ & $0333 ; 0334 ;$ & & \\
\hline
\end{tabular}

\section{Feminist themes}

Having identified the tropes based on discursive elements and connected them with the social context and power relations, it is possible to establish more generalised themes. Following the same structure as above, table 6 displays the five most frequently used themes in the identified campaigns and highlights their connection with the relevant characteristics of an activity system. The numbers in square brackets again represent the exemplary cases:

Table 6. Identified Feminist Themes

\begin{tabular}{|c|c|c|c|c|c|}
\hline $\begin{array}{l}\text { Most Frequent } \\
\text { Feminist Themes }\end{array}$ & $\begin{array}{l}\text { Related Subject in } \\
\text { Video }\end{array}$ & $\begin{array}{l}\text { Related } \\
\text { Object in } \\
\text { Video }\end{array}$ & $\begin{array}{l}\text { Relating } \\
\text { Feminist } \\
\text { Approach }\end{array}$ & $\begin{array}{l}\text { Relating a-priori } \\
\text { Feminist Themes }\end{array}$ & $\begin{array}{l}\text { Salient } \\
\text { Examples }\end{array}$ \\
\hline $\begin{array}{l}\text { I) Women's } \\
\text { Empowerment (15) }\end{array}$ & $\begin{array}{l}\text { societal open- } \\
\text { mindedness, societal } \\
\text { and political } \\
\text { restrictions, } \\
\text { cultural heritage, new } \\
\text { generation, } \\
\text { women in male } \\
\text { dominated branches, } \\
\text { communication styles }\end{array}$ & $\begin{array}{l}\text { poverty, } \\
\text { breastfeeding } \\
\text { mothers, } \\
\text { play } \\
\text { production, } \\
\text { Morse code } \\
\text { sending } \\
\text { bracelet, } \\
\text { kids' } \\
\text { cookbook, } \\
\text { bike locker }\end{array}$ & $\begin{array}{l}\text { social \& } \\
\text { liberal }\end{array}$ & $\begin{array}{l}\text { empowerment, } \\
\text { equal } \\
\text { opportunities, } \\
\text { intact environment }\end{array}$ & $\begin{array}{l}\text { 0101; 0103; } \\
0106 ; 0109 ; \\
0110 ; 0112 ; \\
0213 ; 0214 ; \\
0214 ; 0117 ; \\
0119 ; 0122 ; \\
0324 ; 0328 ; \\
0329 ; 0330 ; \\
0331]\end{array}$ \\
\hline $\begin{array}{l}\text { II) Self Determination } \\
\text { and -realisation (11) }\end{array}$ & $\begin{array}{l}\text { societal taboos, } \\
\text { modern lifestyle, } \\
\text { demanded innovations } \\
\text { in a saturated market, } \\
\text { cultural heritage, } \\
\text { freedom }\end{array}$ & $\begin{array}{l}\text { menstruation, } \\
\text { tech necklace, } \\
\text { sleeping mask, } \\
\text { innovative } \\
\text { pillow, } \\
\text { clothing }\end{array}$ & liberal & $\begin{array}{l}\text { equal } \\
\text { opportunities, } \\
\text { intact environment, } \\
\text { oppression }\end{array}$ & $\begin{array}{l}\text { [0108; 0109; } \\
0112 ; 0116 ; \\
0117 ; 0118 ; \\
0121 ; 0326 ; \\
0330 ; 0333 ; \\
0337 ; 0338 ; \\
0339]\end{array}$ \\
\hline $\begin{array}{l}\text { III) Reflective Body } \\
\text { and Self-Image ( } 7)\end{array}$ & $\begin{array}{l}\text { pressure to appear } \\
\text { equal, } \\
\text { modern lifestyle, } \\
\text { showing character, } \\
\text { cultural heritage, } \\
\text { freedom }\end{array}$ & $\begin{array}{l}\text { bra, } \\
\text { menstruation, } \\
\text { training, } \\
\text { photobook, } \\
\text { clothing }\end{array}$ & social & $\begin{array}{l}\text { sexuality, } \\
\text { oppression }\end{array}$ & $\begin{array}{l}\text { [0106; 0107; } \\
0108 ; 0109 ; \\
0323 ; 0327 ; \\
0333]\end{array}$ \\
\hline
\end{tabular}




\begin{tabular}{|c|c|c|c|c|c|}
\hline $\begin{array}{l}\text { Most Frequent } \\
\text { Feminist Themes }\end{array}$ & $\begin{array}{l}\text { Related Subject in } \\
\text { Video }\end{array}$ & $\begin{array}{l}\text { Related } \\
\text { Object in } \\
\text { Video }\end{array}$ & $\begin{array}{l}\text { Relating } \\
\text { Feminist } \\
\text { Approach }\end{array}$ & $\begin{array}{l}\text { Relating a-priori } \\
\text { Feminist Themes }\end{array}$ & $\begin{array}{l}\text { Salient } \\
\text { Examples }\end{array}$ \\
\hline $\begin{array}{l}\text { IV) Women's and } \\
\text { Family Health (6) }\end{array}$ & $\begin{array}{l}\text { modern lifestyle, } \\
\text { environment issues, } \\
\text { pressure to appear } \\
\text { equal, } \\
\text { cultural heritage }\end{array}$ & $\begin{array}{l}\text { vegetable } \\
\text { blends, } \\
\text { organic tea, } \\
\text { sleeping mask, } \\
\text { training, }\end{array}$ & $\begin{array}{l}\text { social \& } \\
\text { liberal }\end{array}$ & $\begin{array}{l}\text { family; physical } \\
\text { and psychological } \\
\text { health; intact } \\
\text { environment }\end{array}$ & $\begin{array}{l}\text { [0101; 0102; } \\
0104 ; 0116 ; \\
0323 ; 0338]\end{array}$ \\
\hline $\begin{array}{l}\text { V) Sharing Economy } \\
\text { and Community (5) }\end{array}$ & $\begin{array}{l}\text { societal doing-good, } \\
\text { women in men } \\
\text { dominated branches, } \\
\text { modern lifestyle, } \\
\text { capturing moments }\end{array}$ & $\begin{array}{l}\text { group against } \\
\text { poverty, } \\
\text { dolls, } \\
\text { powerbank, } \\
\text { camera }\end{array}$ & $\begin{array}{l}\text { social \& } \\
\text { liberal }\end{array}$ & $\begin{array}{l}\text { equal } \\
\text { opportunities, } \\
\text { intact environment, } \\
\text { empowerment }\end{array}$ & $\begin{array}{l}\text { [0103; 0104; } \\
0111 ; 0325 ; \\
0329]\end{array}$ \\
\hline
\end{tabular}

As table 6 provides an overview of the most frequent feminist themes, in the following paragraphs I elaborate on how these are derived and communicated.

\section{Women's Empowerment (15)}

In many women-initiated campaigns the feminist theme empowerment is aligned with women gaining higher social status. By referring to this, entrepreneurs aim to shed light on and address prevalent social issues, such as women fighting poverty [0103], women being unsuccessful in mostly male-dominated industries such as technology [0118, 0329], as well as gendered perspectives on activities such as sending Morse code messages [0324] and engineering [0120, 0330]. By presuming that women receive equal access to branch specific education, many of the prevailing assumptions are examined. Furthermore, they address contemporary social issues such as refugee employment [0115] and the often-diluted body image of women due to social specifications [0109]. The feminist theme is often linked to tropes such as natural woman [0102, 0119, 0327] and innovative incubator [0115, 0118, 0441, 0323] and hence the intentions of inducing societal change by addressing legal as well as sex-related power issues. By exploring these issues, campaigns strongly address the social status of women. Furthermore, the feminist theme empowerment provides a robust embodiment of discursive elements such as metaphors, symbols, emotional elements and the depiction of a certain (natural) living style. These campaigns are mostly depicting self-conscious women and by that primarily address social feminism. In addition, they aim to change the contemporary social status of women and empower them to aim to be on a par with their male counterparts. Thus, issues relating to liberal feminism are also at the forefront.

\section{Self-Determination and -Realisation (11)}

By addressing the feminist theme self-determination and -realisation in a crowdfunding campaign video, an (often female) entrepreneur aims to reposition herself within a certain entrepreneurial setting. Such settings often demand a strong and inner balanced woman in order to fulfil a certain task. Therefore, campaigns taking up such thoughts refer to topics such as reducing the menstrual pain experienced by women [0108] in which potential short-lasting weaknesses can be overcome. Additionally, they refer to being able to successfully train for a certain body image by adopting training schedule flexibly and ultimately retrieving control and own will [0109]. Furthermore, such campaigns also refer to security issues, and thus offer a solution for women to protect themselves easily [0121] while simultaneously fostering a self-reliant and independent habitus. Fundamentally, these depictions follow tropes such as strong woman [0109, 0112, 0333, 0442] or community [0120, 0331, 0110, 0336, 0214]. These ties show that the feminist theme self-determination is built upon values that foster a great sense of self-appreciation and self-confidence - demanded and supported by a strong community and supporters. Following this idea, female entrepreneurs can flexibly schedule their work-days independently of what others do. In such campaigns these topics are mostly highlighted by relying on discursive elements such as warm colors, metaphors and the depiction of a certain living 
style. Generally, and borrowing from general principles of the empowerment theme, the usage of the theme selfdetermination leads and symbolises advocational guidelines in the context of liberal feminism. Campaigns depicting these avenues do not aim to radically change prevalent socially constructed frameworks, but rather support better communication of its values and norms. Eventually, by using this style entrepreneurs intend to propose future changes in corporate structures, from which a typical picture of successful entrepreneurs might stem.

\section{Reflective Body- and Self-Image (7)}

Continuing the thought of community and social groups, women are often rationalised by the shape and appearance of their bodies. However, in general perceptions the feminist theme body-and self-image often solely depicts societal values which are transported via and created by cultural differences. Instead, body image as such can often be combined with the feminist theme self-determination because women tend to underestimate and pejoratively evaluate themselves when they are not fulfilling certain societal norms. Therefore, campaigns undertaking the theme bodyand self-image cover topics such as creating a calendar with woman showing their natural body [0327] or enhancing the value of women by demonstrating strength via their clothing [0106, 0107, 0333]. In order to reflect such a theme in a campaign, the trope sexuality [0122, 0108, 0334, 0441] as well as natural woman [0102, 0119, 0327] have been used. Referring to and criticizing the contemporary body image of women in society, campaigns strongly address restrictions imposed by power issues and self-imposed values. In doing so the theme "body image" embraces a softer concept of gender through the use of discursive elements such as bright colors, cleanliness, anaphors and also the depiction of a certain living style. Thus, the stream of a social feminist value proposition is applied in these campaigns. By doing so, entrepreneurs mostly act as radical facilitators as they aim to reduce social pressure on women. In campaigns covering this theme, entrepreneurs propose a natural depiction of women's bodies and thus a critical social judgement towards the skills brought by women.

\section{Women's and Family Health (6)}

Taking into account the thoughts of the prior feminist theme body-and self-image, entrepreneurs who address the feminist theme women's and family health in their campaigns often aim to target socially like-minded people. Thinking of multiple families, and especially multiple mothers as a community, a child's health is an always a pressing undertaking. Related issues in such campaigns thus often offer healthy supplements for children or provide organic and environmentally friendly nutrients in drinks and food [0102, 0104], or alternatively provide supports for a healthy positioning of the body and thus contribute to a society's overall health [0116]. At its conceptual base this feminist theme comprises the trope of motherhood and family life, however tropes such as community [0120, 0331, 0110, 0336, 0214] as well as natural woman [0102, 0119, 0327] are also used. In doing so these campaigns aim to address the prevalent challenges women and especially mothers are facing in a fast-moving and at the same time versatile environment of social change. In being strongly socially rooted, power-imposed straits seem more bearable and, in this context, societal inclusion can be seen as a backstop - which ultimately facilitates the external legitimacy of a campaign. To achieve this legitimacy, entrepreneurs following this feminist theme often use discursive elements such as everyday people, anaphors and emotional elements for the depiction of this feminist theme. On the one hand, campaigns following this theme intend to foster an easy, yet rational understanding of what constitutes doing-good for a healthy living style. They do address social issues such as overconsumption, overprotectiveness or the rising number of physically damaged people, but they do not actively seek confrontation with prevalent norms; rather a suggestion of what else can be done is offered. Thus, these campaigns mostly follow a social feminist stream. On the other hand, these campaigns also follow a liberal feminist stream, which addresses the topic of underrepresentation of women in many positions and the reduction of their skills and goals to their overall appearance. In general, in campaigns depicting the feminist theme "health" their social and environmental value is addressed most frequently.

\section{Sharing Economy and Community (5)}

The last feminist theme sharing economy and community differs from the others as it not only addresses women themselves, but also the way they act and interact in a certain social system. Therefore, campaigns referring to this theme are strongly related to others, such as empowerment, poverty or diversity. The focus of the theme however remains on the overall economic, environmental and social doing-good [0103, 0104, 0111, 0325]. Such findings are supported by tropes such as innovate incubators [0115, 0118, 0441], or community [0120, 0331, 0110, 0336, 0214] at the conceptual base. As referred to in prior themes, economic, societal as well as personal challenges seem to be 
less of a burden when shared in a community. An example of practical relevance can be a social venture, which is initially funded and supported by crowdfunding and thus a certain community fosters social inclusion. These ventures and projects aim to support a certain societal group and at the same time help building a sustainable business model. This ultimately leads to greater wealth and less social exclusion due to factors such as restricted access to resources. The feminist theme sharing economy is mostly supported and induced by discursive elements such as rhetorical questions, emotional elements and testimonials during videos. Following this, I see that campaigns entailing such a theme mostly promote an interconnected global community. As mentioned previously, the feminist trope entrepreneurship can be a relevant predecessor to this theme. This is because entrepreneurs often enter collaborations not only to promote their own success, but also to enable a partner to positively participate - and thus create an entrepreneurial win-win situation. The value propositions depicted by such campaigns usually follow a social stream only. The problems solicited by the venture and following its partners are often related to power, poverty and environmental impact, provoked by certain social norms and habits. Based on these findings, I might argue that this feminist theme mostly refers to a social feminist stream; however, by incorporating a multi-national character which further sets new social standards, it also makes strong reference to a liberal feminist stream.

\section{Discussion and epistemological implications}

In order to understand the discourse via entrepreneurial narrations, I follow Venkataraman et al. (2013) in their explanation of artefacts and narrations. Individual narratives within the crowd in particular can thus be seen as being positioned in replicative and formative parts of a social change discourse (Foucault, 1982). Following these assumptions, crowdfunding as a socio-constructivist phenomenon brought to life by the fruitful interplay between the entrepreneurial and societal discourses often acts as the catalyst for social change. At the same time, this dynamic interplay provides an excellent opportunity to gain insights into the necessary distinction between (static) discursive assumptions relating to for example gender and the discursive co-creation of feminist themes within a feminist agenda - an agenda that is often at the root of social change processes.

Following these thoughts, the first research question asks what the rhetorical strategies female entrepreneurs in their narratives in crowdfunding campaign videos are and how they are employed. In the empirical analysis, I find that rhetorical strategies used by women often include a strong emotional language, with the use of metaphors, anaphors, climaxes, and testimonials throughout. Doing so often evokes a strong community sense and directly addresses the emotional base more explicitly than the rational base of the crowd as an audience. This aligns well with a more constructivist understanding of entrepreneurial success factors and related measurements in entrepreneurship literature because these rhetorical strategies strongly address the societal part in the co-creation process of crowdfunding. In the literature I see this also when Parhankangas and Renko (2017) indicate that success is not only affected by linguistic styles but also by the total combination of adequate styles. Their argument is that for newly emerging ventures an adequate linguistic corpus is even more significant than for established companies, indicating that the lack of company history (Stinchcombe, 1965) of start-ups is covered up by an even stronger depiction of entrepreneurial history. As a potential explanatory answer, this difference in rhetorical strategies might also explain the outcome of a PricewaterhouseCoopers $(\mathrm{PwC})$ study, conducted in collaboration with The Crowdfunding Center (2017), scrutinising 450,000 CF campaigns. This study demonstrates early evidence that contrary to many traditional entrepreneurship studies female entrepreneurs often create more successful crowdfunding campaigns than men. Corroboration from literature can also be found in Marlow and Patton (2005), who provide evidence that women perform differently due to a different inherent value-set as men and later in Marlow and McAdam (2013), who state that female entrepreneurs are especially exposed to the static gender-assumptions in entrepreneurship literature whereas their inherent value-set would be strongly rooted in societal issues.

From a feminist perspective, which sees social change as the basis of its agenda, the findings on rhetorical strategies promote a more radical rationale on the understanding of entrepreneurship as social change process. The second research question thus asks what the most common themes in female initiated crowdfunding campaigns are and how these themes can be connected to feminist theory. I find that the a-posteriori themes, as depicted in the crowdfunding videos are indeed well aligned with the a-priori feminist themes from the literature. Examples for this would be a strong focus on female empowerment in a male society, or on overcoming a distorted body image induced by overpowering elements of a social system. The research highlights that female entrepreneurs often combine their entrepreneurial fund-seeking activities with advocacy on societal issues - and hence influence the greater societal discourse and drive a feminist social change agenda.

Given the successful application of feminist theory as a critical lens on crowdfunding campaigns and hence on parts of the contemporary entrepreneurship literature, the third research question asks whether the existing 
epistemological thinking in this field can fully comprehend the "whatness" of crowdfunding. The model (see figure 1) therefore acts as an early epistemological guide for analysing and assessing discursive intentions of entrepreneurs in an environment characterised by social change. With the early application of this model in thiy study guided by feminist literature, I am able to demonstrate its aptness in combining tangible artefacts within a positivist approach with a socially constructed context and an advocacy (radical change) agenda (Sweetman et al., 2010). Furthermore, in the contribution to entrepreneurship research I show that feminist theory indeed offers plenty of explanatory potential for crowdfunding, for instance by providing a novel lens on how entrepreneurial intents may lead to a successful outcome of a campaign.

In the findings I also support the thoughts of Steyaert (2005) and Venkataraman et al. (2013), who argue that entrepreneurial narratives take up and influence the prevalent social discourse and hence the analysis of these micro narrations allows values to be depicted on a societal level. Acknowledging this, I see that social change intentions can be transported accordingly by using feminist themes in crowdfunding campaigns. Even further, I have been able to point out that static gender-presumptions in contemporary entrepreneurship literature limit an adequate inclusion of societal issues and hence, the discourse within an often-radical social (entrepreneurial) change agenda needs to be explored by the ample toolbox of humanist rhetorical analyses. By doing so, I was able to explore the inherent change processes in institutionalised funding strategies.

In terms of implications, I first suggest that crowdfunding success can only be fully understood by exposing (social) entrepreneurship research to more timely research paradigms, embracing a socially constructed ontology of the context while acknowledging eminent structural elements and a potential change agenda as the core of the entrepreneurial intentions. Consequently, a more pragmatic epistemological framework as proposed in this study seems apt. Feminist theory can act as the transcending element between traditional positivist and constructivist notions. Second, and relying on the various entrepreneurial intentions depicted in mostly female initiated crowdfunding videos, I see research on discourse as a fruitful niche and more importantly as a timely way to explore the antecedents of entrepreneurial behaviour (Fauchart and Gruber, 2011). Based on my study and methodological approach, it seems safe to say that further exploration of the true implications of such discourse on the entrepreneurial behaviour and ultimately on the (adapted) performance will provide fruitful future research avenues. As I deliberately and specifically do not look at male-led crowdfunding campaigns a subsequent comparative study of females and males in discursively facilitating social change seems promising for analysing emergent tropes and themes.

Third, from a practitioner's perspective it becomes evident that success in crowdfunding campaigns can be determined by the match between the values proposed in the individual entrepreneurial narrations and the societal values as embedded in the predominant discourse of the target audiences. The nexus between the entrepreneur, the venture and the crowd can be found in the connecting social change motives and needs to be carefully evoked through the means of rhetorical devices and artefacts.

\section{Conclusion}

This paper has set out to examine the themes and rhetoric elements of female run crowdfunding campaigns. Following an idiographic methodology, I have analysed discourse in representations of such campaigns by examining the structure, linguistic usage, visual artefacts and the implied legitimisation strategies for social change. The characteristics identified comprise specific storytelling tools such as displaying every-day-life situations, the featuring of authentic individuals and professionals, and addressing the emotional base via colours, music and language. By doing so, they almost always evoke a doing-good objective and focus more on sustainability and equality with the intention of initiating social change. Due to the emergence of crowdfunding, there has already been a major shift towards more democratic and fair funding of entrepreneurship with co-creation and a distinct shift away from the highly competitive individual-opportunity nexus, towards a more collaborative and sharing economy.

This research has also demonstrated that current paradigmatic frameworks in traditionally functionalist entrepreneurship research might not fully cover the embedded social change perspectives. Therefore, the approach, which studies contextualised discourse while at the same time using pragmatic assumptions in interpreting these perspectives as more generalisable, meaningful factors, may provide a novel way forward. What has become clear is that crowdfunding can indeed be seen as a tool for bringing about a social change perspective into more traditional finance understandings (Lehner \& Harrer, 2019). Not only because of the obvious social aspect of the crowd with its democratic approach to choosing but also because of its embeddedness and interrelatedness to societal values of everyday people and the huge potential for instigating social change. 


\section{References}

Adkins L. (2004) Introduction: Feminism, Bourdieu and after. The Sociological Review 52: 1-18.

Agger B. (2006) Critical Social Theories, Herndon: Paradigm Publishing, ERIC.

Ahl H. (2006) Why Research on Women Entrepreneurs Needs New Directions. Entrepreneurship Theory and Practice 30: 595621.

Ahl H and Marlow S. (2012) Exploring the Dynamics of Gender, Feminism and Entrepreneurship: Advancing Debate to Escape a dead end? Organization 19: 543-562.

Alcoff L. (1988) Cultural Feminism versus Post-Structuralism: The Identity Crisis in Feminist Theory. Journal of Women in Culture and Society 13: 405-436.

Battilana J and Lee M. (2014) Advancing Research on Hybrid Organizing - Insights from the Study of Social Enterprises. Academy of Management Annals 8: 397-441.

Belleflamme P, Lambert T and Schwienbacher A. (2014) Crowdfunding: Tapping the Right Crowd. Journal of business venturing 29: 585-609.

Black N. (1989) Social Feminism: Cornell University Press.

Brown LS. (1992) While Waiting for the Revolution: the Case for a Lesbian Feminist Psychotherapy. Feminism \& Psychology 2: 239-253.

Brown R, Mawson S, Rowe A, et al. (2018) Working the crowd: Improvisational entrepreneurship and equity crowdfunding in nascent entrepreneurial ventures. International Small Business Journal 36: 169-193.

Burrell G and Morgan G. (1979) Sociological Paradigms and Organisational Analysis, London: Heinemann.

Busenitz LW, West III GP, Shepherd D, et al. (2003) Entrepreneurship Research in Emergence: Past Trends and Future Directions. Journal of Management 29: 285-308.

Butler JE and Elliot M. (1993) Bodies that Matter: On the Discursive Limits of Sex, Oxon: Routledge.

Calas MB and Smircich L. (1996) From the Women's Point of View: Feminist Approaches to Organisation Studies. In: Clegg SR and Hardy C (eds) The Handbook of Organization Studies. London: SAGE Publications.

Calas MB and Smircich L. (1999) Past Postmodernism? Reflections and Tentative Directions. Academy of Management Review 24: 649-672.

Calas MB, Smircich L and Bourne KA. (2007) Knowing Lisa? Feminist Analyses of Gender and Entrepreneurship. In: Bilimoria D and Piderit SK (eds) Handbook on women in business and management. Cheltenham: Edward Elgar Publishing 78-105.

Calas MB, Smircich L and Bourne KA. (2009) Extending the Boundaries: Reframing "Entrepreneurship as Social Change" through Feminist Perspectives. Academy of Management Review 34: 552-569.

Carter NM and Williams ML. (2003) Comparing Social Feminism and Liberal Feminism: The Case of new Firm Growth. In: Butler JE (ed) New perspectives on women entrepreneurs. Greenwich: Information Age Publishing, 25-50.

Cliff JE. (1998) Does one Size fit all? Exploring the Relationship between Attitudes Towards Growth, Gender, and Business Size. Journal of business venturing 13: 523-542.

Collins PH. (2002) Black Feminist Thought: Knowledge, Consciousness, and the Politics of Empowerment, Oxon: Routledge.

Colombo MG, Franzoni C and Rossi-Lamastra C. (2015) Internal Social Capital and the Attraction of Early Contributions in Crowdfunding. Entrepreneurship Theory and Practice 39: 75-100.

Coppock V, Haydon D and Richter I. (2014) The Illusions of Post-Feminism: New Women, Old Myths, Oxon: Routledge.

Cowling M and Taylor M. (2001) Entrepreneurial Women and Men: two different Species? Small Business Economics 16: 167175 .

Denzin NK and Lincoln YS. (2011) The Sage Handbook of Qualitative Research, Thousand Oaks: Sage.

Dey P. (2007) The Rhetoric of Social Entrepreneurship: Paralogy and New Language Games in Academic Discourse. In: Steyaert C and Hjorth D (eds) Entrepreneurship As Social Change: A Third New Movements in Entrepreneurship Book. Cheltenham: Edwar Elgar Publishing.

Dey P and Steyaert C. (2012) Social Entrepreneurship: Critique and the Radical Enactment of the Social. Social enterprise journal 8: 90-107.

Fauchart E and Gruber M. (2011) Darwinians, Communitarians, and Missionaires: The Role of Founder Identity in Entrepreneurship. Academy of management journal 54: 935-957.

Ferree MM and Martin PY. (1995) Doing the Work of the Movement: Feminist Organizations. Feminist organizations: Harvest of the new women's movement. Temple University Press, 3-23.

Fischer EM, Reuber AR and Dyke LS. (1993) A theoretical Overview and Extension of Research on Sex, Gender, and Entrepreneurship. Journal of business venturing 8: 151-168.

Foucault M. (1982) The subject and power. Critical inquiry 8: 777-795.

Fraser N. (1997) Justice Interruptus: Critical Reflections on the"Postsocialist" Condition, Oxon: Routledge.

Fraser N and Nicholson L. (1988) Social Criticism without Philosophy: An Encounter between Feminism and Postmodernism. Theory, Culture \& Society 5: 373-394.

Friedan B. (1963) The Problem That Has No Name. In: Plott M and Umansky L (eds) Making Sense of Women's Lives: An Introduction To Women's Studies. Lanham: Rowman \& Littlefield Publishers Inc. , 151-162. 
Gerber EM and Hui J. (2013) Crowdfunding: Motivations and Deterrents for Participation. ACM Transactions on ComputerHuman Interaction (TOCHI) 20: 34: 31-32.

Gilligan C. (1982) In a different voice: Harvard University Press.

Greer MJ and Greene PG. (2003) Feminist Theory and the Study of Entrepreneurship. In: Butler JE (ed) New perspectives on women entrepreneurs. Greenwich: Information Age Publishing, 1-24.

Hall S. (1980) Cultural studies: Two Paradigms. Media, Culture \& Society 2: 57-72.

Harding SG. (2004) The Feminist Standpoint Theory Reader: Intellectual and Political Controversies, New York \& London: Routledge.

Hardy C and Thomas R. (2015) Discourse in a Material World. Journal of Management Studies 52: 680-696.

Haugh H. (2005) A research agenda for social entrepreneurship. Social Enterprise Journal 1: 1-12.

Haugh HM and Talwar A. (2016) Linking Social Entrepreneurship and Social Change: The Mediating Role of Empowerment. Journal of Business Ethics 133: 643-658.

Herzenstein M, Sonenshein S and Dholakia UM. (2011) Tell me a good Story and I may lend you Money: The Role of Narratives in Peer-to-Peer Lending Decisions. Journal of Marketing Research 48: S138-S149.

Jennings JE and Brush CG. (2013) Research on Women Entrepreneurs: Challenges to (and from) the Broader Entrepreneurship Literature? Academy of Management Annals 7: 663-715.

Kaplan C and Grewal I. (1999) Transnational Feminist Cultural Studies: Beyond the Marxism/Poststructuralism/Feminism Divides. In: Kaplan C, Alacron N and Moallem M (eds) Between woman and nation: Nationalisms, transnational feminisms, and the state. Durham: Duke University Press, 349-363.

Labov W. (1972) The Transformation of Experience in Narrative Syntax, Philadelphia: University of Pennsylvania Press.

Landström H, Parhankangas A and Mason C. (2019) Handbook of Research on Crowdfunding: Edward Elgar Publishing.

Lassen I. (2016) Discourse trajectories in a nexus of genres. Discourse Studies 18: 409-429.

Lehner OM. (2012) Social Entrepreneurship Perspectives: Triangulated Approaches to Hybridity. Studies in Business and Economics. Jyväskylä: University of Jyväskylä.

Lehner OM. (2013) Crowdfunding Social Ventures: a Model and Research Agenda. Venture Capital 15: $289-311$.

Lehner OM. (2014) The formation and Interplay of Social Capital in Crowdfunded Social Ventures. Entrepreneurship \& Regional Development 26: 478-499.

Lehner OM and Harrer T. (2019) Crowdfunding revisited: a neo-institutional field-perspective. Venture Capital 21: 75-96.

Lehner OM, Harrer T and Quast M. (2019) Building institutional legitimacy in impact investing: Strategies and gaps in financial communication and discourse. Journal of Applied Accounting Research.

Lehner OM and Nicholls A. (2014) Social finance and crowdfunding for social enterprises: A public-private case study providing legitimacy and leverage. Venture Capital 16: 271-286.

Lehner OM and Weber C. (2016) Challenging Institutional Hybridity in Social Entrepreneurship with Configuration Theory. Academy of Management Academy of Management Proceedings, 10629.

Lewis ET and Carley KM. (2017) Entrepreneurial Culture and Narratives of Self-Experience (tentative title). Pittsburgh: Carnegie Mellon University.

Lewis KV. (2014) Public Narratives of Female Entrepreneurship: Fairy Tale or Fact? Labour \& Industry: a journal of the social and economic relations of work 24: 331-344.

Marlow S and McAdam M. (2013) Gender and entrepreneurship: Advancing Debate and challenging Myths; Exploring the Mystery of the under-performing Female Entrepreneur. International Journal of Entrepreneurial Behavior \& Research 19: 114124.

Marlow S and Patton D. (2005) All Credit to Men? Entrepreneuship, Finance, and Gender. Entrepreneurship theory and practice: 717-735.

Marlow S and Swail J. (2014) Gender, Risk and Finance: why can't a Woman be more like a Man? Entrepreneurship \& Regional Development 26: 80-96.

McRobbie A. (2009) The aftermath of feminism: Gender, culture and social change: Sage.

Meek WR, Pacheco DF and York JG. (2010) The Impact of Social Norms on Entrepreneurial Action: Evidence from the Environmental Entrepreneurship Context. Journal of business venturing 25: 493-509.

Mitchell J. (2000) Psychoanalysis and Feminism: A Radical Reassessment of Freudian Psychoanalysis, New York: Pantheon.

Mohanram R. (1998) (In)visible bodies? Immigrant Bodies and the Constructions of Nationhood in Aotearoa/New Zealand. In: du Plessis R and Lynne A (eds) Feminist Thought in Aotearoa/New Zealand: Crafting Connections/Defining Differences. Auckland: Oxford University Press, 21-29.

Mollick E. (2014) The dynamics of crowdfunding: An exploratory study. Journal of Business Venturing 29: 1-16.

Morgan G. (1980) Paradigms, Metaphors, and Puzzle solving in Organization Theory. Administrative science quarterly: 605622.

Munoz P and Cohen B. (2017) Mapping Out the Sharing Economy: A Configurational Approach to Sharing Business Modeling. Technological Forecasting and Social Change 125: 21-37.

Neergaard H, Frederiksen SH and Marlow S. (2011) The Emperor's new Clothes: Rendering a Feminist Theory of Entrepreneurship Visible. International Council for Small Businesses (ICSB) World Conference. Washington. 
Nielsen KR and Reisch LA. (2016) Crowdfunding for Sustainability: The Role of Value Orientation Frames in Guiding Individual Investment Behavior. The International Conference on Business, Policy and Sustainability. Copenhagen, Denmark.

Noddings N. (1984) Caring: A Feminine Approach to Ethics and Moral Development, Berkeley: University of California Press.

Parhankangas A and Renko M. (2017) Linguistic Style and Crowdfunding Success Among Social and Commercial Entrepreneurs. Journal of business venturing 32: 215-236.

Pettersson K, Ahl H, Berglund K, et al. (2017) In the name of women? Feminist readings of policies for women's entrepreneurship in Scandinavia. Scandinavian Journal of Management 33: 50-63.

Polzin F, Sanders M and Stavlöt U. (2018) Do Investors and Entrepreneurs Match? - Eveidence from The Netherlands and Sweden. Technological Forecasting and Social Change 127: 112-126.

PricewaterhouseCoopers P and The Crowdfunding Center. (2017) Crowdfunding: Unleashing Female Entrepreneurial Potential. In: PwC (ed) Women Unbound.

Radford J. (2013) Emergence of the Gender System on a Crowd-Funding Website: Findings from a Natural Experiment. 108th Annual Meeting of the American Sociological Association. New York.

Shane S and Khurana R. (2001) Bringing Individuals back in: The Effects of Career Experience on new Firm Founding. Academy of Management Proceedings. Academy of Management, F1-F6.

Shane S and Venkataraman S. (2000) The Promise of Entrepreneurship as a Field of Research. Academy of Management Review 25: 217-226.

Shiller RJ. (2017) Narrative Economics. The American Economic Review 107: 967-1004.

Stanley L. (2013) Feminist Praxis: Research, Theory and Epistemology in Feminist Sociology, London: Routledge.

Steyaert C. (2005) Narrative and Discursive Approaches in Entrepreneurship: a Second Movements in Entrepreneurship, Cheltenham: Edward Elgar Publishing.

Steyaert C. (2007) Of Course that is not the whole (toy) Story: Entrepreneurship and the Cat's Cradle. Journal of Business Venturing 22: 733-751.

Stinchcombe AL. (1965) Social Structure and Organizations. In: March JG (ed) Handbook of organizations. Chicago, IL: Rand McNally.

Suchman MC. (1995) Managing legitimacy: Strategic and Institutional Approaches. Academy of Management Review 20: 571610 .

Sweetman D, Badiee M and Creswell JW. (2010) Use of the Transformative Framework in Mixed Methods Studies. Qualitative inquiry 16: 441-454.

Thon C. (2017) Geschlecht-Habitus-Transformation. Pierre Bourdieu: Pädagogische Lektüren. Springer, 129-146.

Tong R. (1998) Postmodern Feminism. In: Tong R (ed) Feminist Thought. Second ed. USA: Westview Press, $193-211$.

Tost LP. (2011) An Integrative Model of Legitimacy Judgments. Academy of management Review 36: 686-710.

Venkataraman S, Sarasvathy SD, Dew N, et al. (2013) Of Narratives and Artifacts. Academy of Management Review 38: 163166.

Youssef AB, Boubaker S and Omri A. (2018) Entrepreneurship and Sustainability: The Need for Innovative and Institutional Solutions. Technological Forecasting and Social Change.

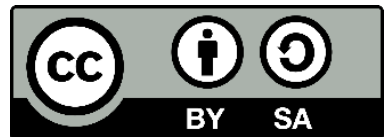

(C) 2019 by the authors. Licensee ACRN Publishing, Austria, Editor in Chief Prof. Dr. Othmar M. Lehner. This article is an open access article distributed under the terms and conditions of the Creative Commons Attribution (CC BY SA) license (https://creativecommons.org/licenses/by-sa/4.0/) 


\section{Appendices}

\section{Appendix A - A Detailed List and Overview of the Selected Cases and Statistics}

\begin{tabular}{|c|c|c|c|c|c|c|}
\hline Number & Name & $\begin{array}{c}\text { Funding Sum } \\
\text { USD }\end{array}$ & $\begin{array}{c}\text { Funding Goal } \\
\text { USD }\end{array}$ & $\begin{array}{c}\text { Category on } \\
\text { Platform }\end{array}$ & Type of CF & Context \\
\hline 0101 & $\begin{array}{l}\text { Healthy Habit } \\
\text { Challenge }\end{array}$ & $\$$ & $\$ \quad 1,378.81$ & Health \& Fitness & Reward & $\begin{array}{l}\text { Slovakia / } \\
\text { Europe }\end{array}$ \\
\hline 0301 & also Kickstarter & 46.67 & $\$ \quad 1,378.81$ & Events & Reward & \\
\hline 0102 & $\begin{array}{l}\text { EasyPeasie } \\
\text { Veggie Blends }\end{array}$ & $72 ., 00$ & $\$ 38,500.00$ & Food \& Beverages & Reward & America \\
\hline 0103 & $\begin{array}{l}\text { Women } \\
\text { Participation in } \\
\text { Fighting } \\
\text { Poverty }\end{array}$ & $\$$ & $\$ 2.000 .00$ & Food \& Beverages & Reward & $\begin{array}{l}\text { Uganda / } \\
\text { global }\end{array}$ \\
\hline 0104 & $\begin{array}{l}\text { Good Earth: } \\
\text { World's First } \\
\text { Organic Tea } \\
\text { Club }\end{array}$ & 40.00 & $\$ 50,000.00$ & Health \& Fitness & Reward & $\begin{array}{l}\text { Canada / } \\
\text { global }\end{array}$ \\
\hline 0105 & $\begin{array}{l}\text { New Nail Art } \\
\text { Jewelry }\end{array}$ & $\$$ & $\$ \quad 1,500.00$ & Fashion \& Clothing & Reward & America \\
\hline 0106 & $\begin{array}{l}\text { Kojo - } \\
\text { Activewear }\end{array}$ & 672.00 & $\$ 27,500.00$ & Fashion \& Clothing & Reward & $\begin{array}{l}\text { Slovakia / } \\
\text { mothers }\end{array}$ \\
\hline 0107 & Evolution Bra & $\$ 1,607,107.00$ & $\$ 43,000.00$ & In Demand & Reward & $\begin{array}{l}\text { America / } \\
\text { global }\end{array}$ \\
\hline 0307 & also Kickstarter & $\$ 1,105,177.00$ & $\$ 30,000.00$ & & Reward & \\
\hline 0108 & $\begin{array}{l}\text { Livia - The } \\
\text { Offswitch for } \\
\text { Menstrual Pain }\end{array}$ & $\$ 1,694,104.00$ & $\$ 126,000.00$ & In Demand & In Demand & global \\
\hline 0109 & BodyBoss 2.0 & $\$ 972,534.00$ & $\$ 26,000.00$ & Health \& Fitness & Reward & America \\
\hline 0110 & $\begin{array}{l}\text { She Started it } \\
\text { Documentary } \\
\text { Phase } 2\end{array}$ & $\$ \quad 32,715.00$ & $\$ 32,000.00$ & In Demand & In Demand & $\begin{array}{l}\text { San } \\
\text { Francisco / } \\
\text { America }\end{array}$ \\
\hline 0111 & $\begin{array}{l}\text { Cuddle and } \\
\text { Kind }\end{array}$ & $\$ 446,081.00$ & $\$ 31,000.00$ & In Demand & In Demand & $\begin{array}{l}\text { Canada / } \\
\text { global }\end{array}$ \\
\hline 0112 & $\begin{array}{l}\text { Dipper Audio } \\
\text { Necklace }\end{array}$ & $\$ \quad 54,900.00$ & $\$ 50,000.00$ & In Demand & In Demand & $\begin{array}{l}\text { America / } \\
\text { global }\end{array}$ \\
\hline 0213 & $\begin{array}{l}\text { Daniel \& Sherei } \\
\text { Are Adopting }\end{array}$ & $\$ \quad 8,346.00$ & $\$ 28,429.00$ & $\begin{array}{l}\text { Celebration } \\
\text { Fundraising }\end{array}$ & Donation & America \\
\hline 0214 & Women's Plays & 672.00 & $\$ \quad 8,000.00$ & $\begin{array}{l}\text { Community } \\
\text { Fundraising }\end{array}$ & Donation & America \\
\hline 0115 & $\begin{array}{l}\text { Help Refugees } \\
\text { with Baby } \\
\text { Carriers }\end{array}$ & $\$ 177,456.00$ & $\$ 11,000.00$ & In Demand & In Demand & global \\
\hline 0116 & Illumy & \$ $\quad 46,975.00$ & $\$ 31,000.00$ & Health \& Fitness & Reward & $\begin{array}{l}\text { America / } \\
\text { global }\end{array}$ \\
\hline 0117 & AllBe1 & \$ $181,110.00$ & $\$ 66,500.00$ & $\begin{array}{l}\text { Telephone \& } \\
\text { Accessory }\end{array}$ & Reward & global \\
\hline 0118 & $\begin{array}{l}\text { Flexound } \\
\text { HUMU }\end{array}$ & $\$ \quad 29,410.00$ & $\$ 35,000.00$ & Audio & Reward & $\begin{array}{l}\text { Finland / } \\
\text { global }\end{array}$ \\
\hline 0119 & $\begin{array}{l}\text { Mette Damiri's } \\
\text { Debut Album }\end{array}$ & 668.19 & $\$ \quad 5,833.41$ & Audio & Reward & $\begin{array}{l}\text { Rome / } \\
\text { Italy }\end{array}$ \\
\hline 0120 & $\begin{array}{l}\text { LIVIN Hive for } \\
\text { Insects }\end{array}$ & \$ $145,459.00$ & $\$ 00,000.00$ & Regional Ventures & Reward & global \\
\hline 0121 & SkyBell & $\$ 606,814.00$ & $\$ 100,000.00$ & In Demand & In Demand & America \\
\hline 0122 & Hullabaloo & $\$ 470,726.00$ & $\$ 80,000.00$ & Film & Reward & $\begin{array}{l}\text { Los } \\
\text { Angeles }\end{array}$ \\
\hline
\end{tabular}




\begin{tabular}{|c|c|c|c|c|c|c|}
\hline Number & Name & $\begin{array}{c}\text { Funding Sum } \\
\text { USD }\end{array}$ & $\begin{array}{c}\text { Funding Goal } \\
\text { USD }\end{array}$ & $\begin{array}{l}\text { Category on } \\
\text { Platform }\end{array}$ & Type of CF & Context \\
\hline 0323 & $\begin{array}{l}\text { Apocalypse } \\
\text { Survival } \\
\text { Training } \\
\end{array}$ & $\$ \quad 19,023.10$ & $\$ 12,494.65$ & Apps & Reward & London \\
\hline 0324 & JewelBots & $\$ 166,945.00$ & $\$ 30,000.00$ & Wearables & Reward & $\begin{array}{l}\text { New York / } \\
\text { global }\end{array}$ \\
\hline 0325 & Foxshot & $\$ \quad 58,886.00$ & $\$ \quad, 500.00$ & Gadgets & Reward & global \\
\hline 0326 & Daydream & $\$ \quad 5,268.00$ & $\$ \quad, 000.00$ & $\begin{array}{l}\text { Music / Country \& } \\
\text { Folk }\end{array}$ & Reward & $\begin{array}{l}\text { Denver / } \\
\text { global }\end{array}$ \\
\hline 0327 & Average Girl & $\$ \quad 2,585.27$ & $\$ 5,628.31$ & Art Book & Reward & global \\
\hline 0328 & Eat Offbeat & $\$ \quad 39,327.00$ & $\$ 50,000.00$ & Cook Book & Reward & $\begin{array}{l}\text { New York / } \\
\text { America }\end{array}$ \\
\hline 0329 & DoubleUp & $\$ \quad 5,268.76$ & $\$ 52,470.25$ & Gadgets & Reward & $\begin{array}{l}\text { Australia / } \\
\text { global }\end{array}$ \\
\hline 0330 & Tex-Lock & $\$ 266,582.59$ & $\$ 53,031.00$ & Product design & Reward & $\begin{array}{l}\text { Europe / } \\
\text { global / } \\
\text { many bikes }\end{array}$ \\
\hline 0331 & $\begin{array}{l}\text { The Lemonade } \\
\text { Stand } \\
\text { Cookbook }\end{array}$ & $\$ \quad 9,828.00$ & $\$ 10,000.00$ & Kid's Book & Reward & America \\
\hline 0332 & Magpie Goose & $\$ \quad 51,448.58$ & $\$ 14,991.50$ & Clothing & Reward & $\begin{array}{l}\text { Australia / } \\
\text { social cause } \\
\text { / global }\end{array}$ \\
\hline 0333 & Lorica Clothing & $\$ \quad 52,318.00$ & $\$ 10,000.00$ & Clothing & Reward & $\begin{array}{l}\text { America / } \\
\text { global }\end{array}$ \\
\hline 0334 & $\begin{array}{l}\text { Lydia Lunch } \\
\text { Documentary }\end{array}$ & $\$ \quad 9,535.00$ & $\$ 50,000.00$ & Film/Documentary & Reward & $\begin{array}{l}\text { America / } \\
\text { global }\end{array}$ \\
\hline 0335 & $\begin{array}{l}\text { Doubleclicks' } \\
\text { Album }\end{array}$ & $\$ \quad 65,689.00$ & $\$ 35,000.00$ & Music & Reward & $\begin{array}{l}\text { America / } \\
\text { global }\end{array}$ \\
\hline 0336 & $\begin{array}{l}\text { SugarHill } \\
\text { Creamery }\end{array}$ & $\$ \quad 11,654.00$ & $\$ 12,000.00$ & Restaurants & Reward & $\begin{array}{l}\text { NY / } \\
\text { Harlem }\end{array}$ \\
\hline 0337 & Kancy & $\$ \quad 10,358.34$ & $\$ 22,513.23$ & Gadgets & Reward & America \\
\hline 0338 & Purple Pillow & $\$ 2,640,852.00$ & $\$ 25,000.00$ & Technology & Reward & global \\
\hline 0339 & $\begin{array}{l}\text { Hey - Touching } \\
\text { Bracelet }\end{array}$ & $\$ 137,551.81$ & $\$ 32,577.50$ & Wearables & Reward & global \\
\hline 0340 & $\begin{array}{l}\text { Space Captain } \\
\text { Issue } 4\end{array}$ & $\$ \quad 3,783.38$ & $\$ \quad 624.73$ & Comics & Reward & global \\
\hline 0441 & Amanda Palmer & $38.461,26$ & $\$$ & Art & Reward & America \\
\hline 0442 & Monica Byrne & $2.907,16$ & $\$$ & Art & Reward & America \\
\hline \multicolumn{7}{|c|}{42 Crowdfunding Cases } \\
\hline \multicolumn{2}{|l|}{ Total Sum } & $\$ 11,180,781.78$ & $\$ 1,450,851.19$ & & & \\
\hline \multicolumn{2}{|c|}{$\begin{array}{l}\text { Total Investment Sum } \\
\text { Platforms }\end{array}$} & & $\$ 3,782,453,282.00$ & & & \\
\hline
\end{tabular}




\section{Appendix B - Collected Scores per Project}

\begin{tabular}{|c|c|c|c|c|}
\hline Number & Name & $\begin{array}{l}\text { Feminist } \\
\text { Score }\end{array}$ & Impact Score & $\begin{array}{c}\text { Team } \\
(1=f, 2=m, 3=\text { mix })\end{array}$ \\
\hline 0101 & $\begin{array}{l}\text { Healthy Habit } \\
\text { Challenge }\end{array}$ & 3 & 2 & 3 \\
\hline 0301 & also Kickstarter & & & \\
\hline 0102 & $\begin{array}{l}\text { EasyPeasie } \\
\text { Veggie Blends }\end{array}$ & 3 & 3 & 1 \\
\hline 0103 & $\begin{array}{l}\text { Women } \\
\text { Participation in } \\
\text { Fighting } \\
\text { Poverty }\end{array}$ & 4 & 5 & 1 \\
\hline 0104 & $\begin{array}{l}\text { Good Earth: } \\
\text { World's First } \\
\text { Organic Tea } \\
\text { Club }\end{array}$ & 2 & 4 & 3 \\
\hline 0105 & $\begin{array}{l}\text { New Nail Art } \\
\text { Jewelry }\end{array}$ & 5 & 0 & 1 \\
\hline 0106 & $\begin{array}{l}\text { Kojo - } \\
\text { Activewear }\end{array}$ & 3 & $2-3$ & 1 \\
\hline 0107 & Evolution Bra & 3 & 2 & 1 \\
\hline 0307 & also Kickstarter & & & \\
\hline 0108 & $\begin{array}{l}\text { Livia - The } \\
\text { Offswitch for } \\
\text { Menstrual Pain }\end{array}$ & 3 & 1 & 3 \\
\hline 0109 & BodyBoss 2.0 & 2 & 0 & 2 \\
\hline 0110 & $\begin{array}{l}\text { She Started it } \\
\text { Documentary } \\
\text { Phase } 2\end{array}$ & 4 & $3-4$ & 1 \\
\hline 0111 & $\begin{array}{l}\text { Cuddle and } \\
\text { Kind }\end{array}$ & 2 & 4 & 3 \\
\hline 0112 & $\begin{array}{l}\text { Dipper Audio } \\
\text { Necklace }\end{array}$ & $2-3$ & 1 & 1 \\
\hline 0213 & $\begin{array}{l}\text { Daniel \& Sherei } \\
\text { Are Adopting }\end{array}$ & 2 & $2-3$ & 3 \\
\hline 0214 & Women's Plays & 5 & 3 & 1 \\
\hline 0115 & $\begin{array}{l}\text { Help Refugees } \\
\text { with Baby } \\
\text { Carriers }\end{array}$ & 4 & 5 & 1 \\
\hline 0116 & Illumy & 2 & 2 & 2 \\
\hline 0117 & AllBe1 & 2 & 2 & 2 \\
\hline 0118 & $\begin{array}{l}\text { Flexound } \\
\text { HUMU }\end{array}$ & 3 & 2 & 3 \\
\hline 0119 & $\begin{array}{l}\text { Mette Damiri's } \\
\text { Debut Album }\end{array}$ & 4 & 1 & 1 \\
\hline 0120 & $\begin{array}{l}\text { LIVIN Hive for } \\
\text { Insects }\end{array}$ & 4 & 1 & 1 \\
\hline 0121 & SkyBell & 2 & 0 & 2 \\
\hline 0122 & Hullabaloo & 3 & 1 & 2 \\
\hline 0323 & $\begin{array}{l}\text { Apocalypse } \\
\text { Survival } \\
\text { Training } \\
\end{array}$ & 5 & 1 & 1 \\
\hline 0324 & JewelBots & 3 & 3 & 1 \\
\hline 0325 & Foxshot & 2 & 1 & 1 \\
\hline 0326 & Daydream & 3 & 1 & 1 \\
\hline 0327 & Average Girl & 5 & 4 & 1 \\
\hline 0328 & Eat Offbeat & 3 & 5 & 3 \\
\hline
\end{tabular}




\begin{tabular}{|l|l|c|c|c|}
\hline Number & \multicolumn{1}{|c|}{ Name } & $\begin{array}{c}\text { Feminist } \\
\text { Score }\end{array}$ & Impact Score & $\begin{array}{c}\text { Team } \\
\text { (1=f, 2=m, 3=mix })\end{array}$ \\
\hline 0329 & DoubleUp & 2 & 1 & 1 \\
\hline 0330 & Tex-Lock & 2 & 1 & 1 \\
\hline 0331 & $\begin{array}{l}\text { The Lemonade } \\
\text { Stand } \\
\text { Cookbook }\end{array}$ & 4 & 4 & 1 \\
\hline 0332 & Magpie Goose & 5 & 4 & 1 \\
\hline 0333 & Lorica Clothing & 4 & 0 & 1 \\
\hline 0334 & $\begin{array}{l}\text { Lydia Lunch } \\
\text { Documentary }\end{array}$ & 4 & 1 & 3 \\
\hline 0335 & $\begin{array}{l}\text { Doubleclicks' } \\
\text { Album }\end{array}$ & 4 & 1 & 2 \\
\hline 0336 & $\begin{array}{l}\text { SugarHill } \\
\text { Creamery }\end{array}$ & 3 & 2 & 2 \\
\hline 0337 & Kancy & 1 & 1 & 2 \\
\hline 0338 & Purple Pillow & 2 & 3 & 1 \\
\hline 0339 & $\begin{array}{l}\text { Hey - Touching } \\
\text { Bracelet }\end{array}$ & 2 & 2 & 1 \\
\hline 0340 & $\begin{array}{l}\text { Space Captain } \\
\text { Issue 4 }\end{array}$ & 1 & 1 & 2 \\
\hline 0441 & Amanda Palmer & 4 & 2 & 1 \\
\hline 0442 & Monica Byrne & 4 & & \\
\hline
\end{tabular}

\section{Appendix C - A Detailed List of Discursive Elements, Tropes and Feminist Themes}

\begin{tabular}{|l|l|l|}
\hline 1) Discursive Elements & 2) Tropes & 3) Feminist Themes \\
\hline Action & Alternative Clothing & Anti-Violence \\
\hline Anaphors & Babies/ Nursing & Body Image \\
\hline Augmented Reality & Bee Queen & Climate \\
\hline Best-Of Scenes & Coincidences / Luck & Critique \\
\hline Bird Perspective & Community & Democracy \\
\hline Bright & Comparison & Diversity \\
\hline Citations in the Beginning/End & Critique on Beauty Stereotypes & Empowerment \\
\hline Cleanliness & Cultural heritage & Equality \\
\hline Cleanliness & Discrimination & Freedom/Independency \\
\hline Climax & Dominant men & Gender \\
\hline Clothes comfortable & Family life & Health \\
\hline Colourful & Healthy Environment & Humanity \\
\hline Colours & Innovative Incubator & Illusion \\
\hline Community sense & Love Story & Inclusion \\
\hline Dark & Motherhood & Justice \\
\hline Depiction of Countryside & Natural Woman & LGBT \\
\hline Depiction of Living Style & Objectification (bare skin etc.) & Marxist \\
\hline Emotional elements & Resistance & Migration \\
\hline Every day people & Role Change (vs. Tradition/ Stereotype) & Nudity \\
\hline Formal & Security & Nutrition \\
\hline Frog perspective & Sexuality (self-determined) & Patriarchal Structures \\
\hline Humor & Sisterhood & Poverty \\
\hline Informal & Strong Woman & Self Determination \\
\hline Internationality & Submission/Dominance & Sharing Economy \\
\hline Irony & Tech Women & Sustainability \\
\hline Language (informal/formal) & Third World Social Problems & Transformation \\
\hline Legitimacy & Weak Men & \\
\hline Lifestyle product & Well-being & \\
\hline
\end{tabular}




\begin{tabular}{|l|l|l|}
\hline Male/Female Narrator & Wise Woman & \\
\hline Metaphors & & \\
\hline Music (dramatic, silent etc.) & & \\
\hline Number of Pan Shots & & \\
\hline Parody & & \\
\hline Personification & & \\
\hline Pictures & & \\
\hline $\begin{array}{l}\text { Postmodern Aspects (intertextuality, } \\
\text { fragmented voice, repetition) }\end{array}$ & & \\
\hline $\begin{array}{l}\text { Presentation Support (ppt, visualization, } \\
\text { etc.) }\end{array}$ & & \\
\hline Professional stepping in & & \\
\hline Rhetorical Questions & & \\
\hline Rhymes & & \\
\hline Satire & & \\
\hline Sharing & & \\
\hline Smiling & & \\
\hline Sound Background and Foreground & & \\
\hline Statements & & \\
\hline Surrealism & & \\
\hline Symbols/Brands & & \\
\hline Testimonial & & \\
\hline
\end{tabular}

